\title{
Gangguan Ginjal Akut et Kausa Sepsis: Laporan Kasus
}

\section{Jaquelene D. Kairupan, ${ }^{1}$ Stella Palar ${ }^{2}$}

\author{
${ }^{1}$ PPDS Bagian Ilmu Penyakit Dalam Fakultas Kedokteran Universitas Sam Ratulangi Manado \\ ${ }^{2}$ Bagian Ilmu Penyakit Dalam Fakultas Kedokteran Universitas Sam Ratulangi Manado \\ Email: jaquelenekairupan@ gmail.com
}

\begin{abstract}
Acute kidney injury (AKI) is a sudden episode of decreased renal function that occurs within a few hours until a few weeks, followed by renal failure in excretion of nitrogen-waste products with or without imbalance of fluid and electrolytes. Sepsis is the main cause of critical illnesses as well as the main cause of AKI, albeit, the pathophysiology of AKI due to sepsis is not jet fully understood. We reported a female patient aged 35 years with AKI due to sepsis caused by abscess of suprafundal uterine that occured due to nosocomial infection post laparoscopy of utero myoma. Diagnosis was based on anamnesis, physical examination, and laboratory examination as well as radiology examination. The patient had been given an adequate antibiotic treatment with infection source control, renal supportive therapy using intermittent hemodialysis, exploration surgery, and abscess drainage. The prognosis of this patient was good since the condition of sepsis was resolved and the renal supportive therapy of hemodialysis improved her renal function.
\end{abstract}

Keywords: acute kidney injury, sepsis

\begin{abstract}
Abstrak: Gangguan ginjal akut (GgGA) adalah penurunan fungsi ginjal yang terjadi mendadak dalam beberapa jam sampai beberapa minggu, diikuti oleh kegagalan ginjal untuk mengekskresi sisa metabolisme nitrogen dengan atau tanpa disertai terjadinya gangguan keseimbangan cairan dan elektrolit. Sepsis merupakan penyebab utama dari penyakit kritis dan juga merupakan faktor penyebab paling umum untuk terjadinya GgGA namun patofisiologi terjadinya GgGA akibat sepsis belum dipahami dengan jelas. Kami melaporkan seorang pasien wanita usia 35 tahun dengan GgGA akibat sepsis yang disebabkan oleh abses suprafundus uteri dengan kausa infeksi nosokomial pasca laparoskopi mioma uteri. Diagnosis ditegakkan berdasarkan anamnesis, pemeriksaan fisik, pemeriksaan laboratorium dan radiologi. Pasien telah diberikan pengobatan antibiotik adekuat dengan kontrol sumber infeksi, terapi suportif ginjal menggunakan intermittent hemodialysis, operasi eksplorasi, dan drainase abses. Prognosis pada pasien ini ialah baik bila kondisi sepsis teratasi dan terapi suportif ginjal hemodialisis memberi hasil perbaikan fungsi ginjal.
\end{abstract}

Kata kunci: gangguan ginjal akut (GgGA), sepsis

\section{PENDAHULUAN}

Gangguan ginjal akut (GgGA) adalah penurunan fungsi ginjal yang terjadi mendadak dalam beberapa jam sampai beberapa minggu, diikuti oleh kegagalan ginjal untuk mengekskresi sisa metabolisme nitrogen dengan atau tanpa disertai terjadinya gangguan keseimbangan cairan dan elektrolit. Kejadian GgGA di Intensive Care Unit (ICU) dewasa dilaporkan berkisar 16-67\% .
Penelitian kohort selama 10 tahun yang melibatkan lebih dari 90.000 pasien dan lebih dari $20 \mathrm{ICU}$, menunjukkan peningkatan kejadian GgGA sebesar 2,8\% per tahun. ${ }^{1}$

Gangguan ginjal akut secara garis besar dibagi menjadi 3 bagian, yaitu pre-renal, renal (intrinsik), post-renal. Penyebab GgGA pre-renal ialah hipoperfusi ginjal yang dapat disebabkan oleh hipovolemia atau menurun- 
nya volume sirkulasi yang efektif. Gangguan ginjal akut renal (intrinsik) dapat disebabkan oleh glomerulonefritis akut, vaskulitis, nefritis insterstisial akut dan paling sering karena nekrosis tubular akut (NTA) akibat sepsis sedangkan GgGA post-renal disebabkan oleh adanya obstruksi intrarenal dan ekstrarenal. ${ }^{1,2}$

Sepsis merupakan penyebab utama dari penyakit kritis dan juga merupakan faktor penyebab paling umum untuk terjadinya GgGA. Pada dewasa dan anak, sepsis menyumbang 26-50\% dari semua GgGA di negara maju, dibandingkan dengan $7-10 \%$ GgGA akibat penyakit ginjal primer. ${ }^{1,2}$

Saat ini pemahaman tentang patofisiologi terjadinya GgGA akibat sepsis belum diketahui secara lengkap. Hipoperfusi yang dimediasi oleh sepsis menyebabkan nekrosis tubular diduga sebagai patofisiologi utama untuk GgGA akibat sepsis, namun demikian, semakin banyak bukti yang menantang paradigma ini. Banyak penyebab yang sekarang diakui berperan dalam terjadinya GgGA akibat sepsis, termasuk cedera iskemia-reperfusi pada glomerulus, inflamesi pada bagian spesifik nefron, hipoksia dan/atau stres oksidatif, sitokin dan kemokin menyebabkan cedera langsung pada tubulus, serta apoptosis tubular dan mesenkimal. Tingkat keparahan cedera dan hasil akhir buruk terhadap GgGA akibat sepsis disebabkan karena keterlambatan pengenalan dini dari cedera. ${ }^{2}$

Penatalaksanaan GgGA akibat sepsis ialah dengan pemberian cairan yang adekuat, kontrol terhadap asidosis, antibiotik adekuat, pemberian vasopresor apabila terjadi hipotensi, dan terapi suportif ginjal. Indikasi terapi suportif ginjal pada pasien dengan GgGA bila adanya asidosis metabolik, kelebihan cairan, sindrom uremia, gangguan elektrolit, dan intoksikasi alkohol. ${ }^{3}$

Pemahaman terjadinya GgGA akibat sepsis belum diketahui secara lengkap; oleh karena itu kami mengangkat sebuah kasus GgGA akibat sepsis yang dirawat di RSUP Prof. Dr. R. D. Kandou Manado dalam laporan kasus ini.

\section{LAPORAN KASUS}

Seorang pasien wanita, usia 35 tahun, suku Minahasa, agama Kristen, pekerjaan ibu rumah tangga, datang ke RSUP Prof. Dr. R. D. Kandou Manado pada tanggal 17 Juli 2018 di Instalasi Rawat Darurat Bedah yang kemudian dikonsulkan ke Bagian Ilmu Penyakit Dalam (IPD) pada tanggal 18 Juli 2018.

Keluhan utama pasien ialah sesak napas sejak 5 hari yang lalu, sesak dirasakan saat istirahat maupun berjalan. Nyeri perut menjalar sampai belakang dirasakan hilang timbul sejak \pm 11 hari yang lalu setelah pasien dioperasi atas indikasi mioma uteri. Mual dan muntah dialami pada saat pasien makan. Pasien juga mengeluhkan lemah badan serta bengkak pada kedua tangan dan tungkai. Demam sejak 1 minggu yang lalu hilang timbul. Batuk disangkal. Buang air kecil sering dengan volume $\pm 2000 \mathrm{~mL} / 24$ jam. Buang air besar tidak ada keluhan. Pasien saat ini sedang haid dengan hari pertama haid terakhir (HPHT) tanggal 13 Juli 2018.

Riwayat penyakit sebelumnya ialah pasien pernah dirawat di RS Siloam Manado dan dilakukan operasi laparoskopi atas indikasi mioma uteri pada tanggal 7 Juli 2018. Hasil laboratorium pre-operatif tanggal 4 Juli 2018 ialah sebagai berikut: $\mathrm{Hb}$ $13,8 \mathrm{~g} / \mathrm{dL}$; leukosit 8.440/uL; ureum 25 $\mathrm{mg} / \mathrm{dL}$; kreatinin $0,7 \mathrm{mg} / \mathrm{dL}$; SGOT $14 \mathrm{U} / \mathrm{L}$; SGPT $13 \mathrm{U} / \mathrm{L} ; \mathrm{Na} 139 \mathrm{mEq} / \mathrm{L} ; \mathrm{K}$ 4,1 mEq/L; dan pemeriksaan foto toraks tanggal 3 Juli 2018 dengan kesan tidak tampak kelainan signifikan. Pasien dirawat selama 10 hari di RS Siloam Manado, dipulangkan pada tanggal 12 Juli 2018, kemudian masuk ke RS Bethesda Tomohon pada tanggal 13 Juli 2018 dengan keluhan sesak napas, demam tinggi, dan disertai nyeri perut yang terasa lebih sering. Hasil laboratorium tanggal 13 Juli 2018 ialah sebagai berikut: $\mathrm{Hb} 9$ g/dL; eritrosit 3x10\% 23.240/ul; trombosit 215.000/uL; MCH 30 pg; MCHC 35,6 g/dL; MCV 84,2 fL; ureum $133 \mathrm{mg} / \mathrm{dL}$; kreatinin 9,1 mg/dL; Na 117 $\mathrm{mEq} / \mathrm{L} ; \mathrm{K} 4,1 \mathrm{mEq} / \mathrm{L} ; \mathrm{Cl} 84 \mathrm{mEq} / \mathrm{L}$. Hasil rekam jantung kesan dalam batas normal. 
Hasil foto toraks tanggal 13 Juli 2018 dengan kesan kardiomegali Cardiothoracic Ratio (CTR) $56 \%$, efusi pleura bilateral minimal, corakan vaskularisasi paru meningkat, dan suspek efusi perikardial. Hasil laboratorium tanggal 14 Juli 2018 ialah sebagai berikut: ureum $133 \mathrm{mg} / \mathrm{dL}$; kreatinin $9,3 \mathrm{mg} / \mathrm{dL}$; protein total $6,4 \mathrm{~g} / \mathrm{dL}$; albumin 3,2 g/dL; globulin 3,2 g/dL. Hasil laboratorium tanggal 17 Juli $2018 \mathrm{Hb} \mathrm{8,2}$ $\mathrm{g} / \mathrm{dL}$; eritrosit 2,76×10\% $/ \mathrm{uL}$; Ht 23\%; leukosit 29.280/uL; trombosit 398.000/uL; MCH 29,7 pg; MCHC 35,7 g/dL; MCV 83,2 fL; LED 80; GDP 83 mg/dL; ureum 148 mg/dL; kreatinin $10 \mathrm{mg} / \mathrm{dL}$; asam urat $16 \mathrm{mg} / \mathrm{dL} ; \mathrm{Na}$ $113 \mathrm{mEq} / \mathrm{L} ; \mathrm{K}$ 4,1 mEq/L; Cl $79 \mathrm{mEq} / \mathrm{L}$. Hasil ultrasonografi (USG) abdomen tanggal 17 Juli 2018 dengan kesan massa hipoekoik di fundus uteri diagnois banding (dd) hematoma, pseudokista, dan didapatkan cairan bebas di kavum Douglasi. Saat perawatan di RS Bethesda Tomohon pasien didiagnosis dengan acute heart failure dan GgGA. Terapi selama perawatan ialah injeksi furosemide $20 \mathrm{mg}$ IV bolus dilanjutkan drips furosemide $120 \mathrm{mg} \mathrm{IV}$, spironolakton $50 \mathrm{mg} 1 \mathrm{x} /$ hari, gliseril trinitrat $2,5 \mathrm{mg}$ 2x/hari, dan injeksi ampicillin-sulbactam 1,5 g 3x/hari IV. Pasien kemudian dirujuk ke RSUP Prof. Dr. R. D. Kandou Manado pada tanggal 17 Juli 2018. Riwayat penyakit keluarga, ibu kandung pasien menyandang diabetes melitus tipe 2 terkontrol dengan insulin. Riwayat sosial merokok dan alkohol disangkal pasien. Riwayat alergi tidak ada.

Pemeriksaan fisik tanggal 18 Juli 2018 saat pasien dikonsulkan ke Bagian IPD didapatkan keadaan umum tampak sakit sedang dengan kesadaran kompos mentis, berat badan $65 \mathrm{~kg}$, tinggi badan $155 \mathrm{~cm}$, tekanan darah 100/70 mmHg, nadi $110 \mathrm{x} /$ menit reguler, isi cukup, frekuensi pernapasan $26 \mathrm{x} /$ menit, suhu badan aksiler $38,9^{\circ} \mathrm{C}$. Konjungtiva anemis, sklera tidak ikterik, bibir tidak sianosis, tekanan vena jugularis $5+4 \mathrm{~cm} \mathrm{H}_{2} \mathrm{O}$, trakea letak di tengah, tidak didapatkan pembesaran kelenjar getah bening leher. Dada tampak simetris saat statis dan dinamis, stem fremitus teraba sama pada kedua lapang paru, perkusi sonor, auskultasi suara pernapasan vesikuler kiri dan kanan, terdapat ronki basah kasar pada kedua lapang paru dan tidak ada wheezing. Pemeriksaan jantung didapatkan inspeksi iktus kordis tidak tampak, palpasi iktus kordis tidak teraba, perkusi batas jantung kanan di sela iga $\mathrm{V}$ linea sternalis kanan, batas kiri jantung sela iga $\mathrm{V}$ linea mid klavikularis kiri, auskultasi denyut jantung reguler, suara jantung I dan II normal, tidak ada bising dan gallop. Pada pemeriksaan abdomen tampak distensi, luka operasi terawat, bising usus normal, defans muskular tidak ada, hati dan limpa tidak teraba, shifting dullness positif, ballotement ginjal tidak teraba, nyeri tekan pada daerah epigastrium, dan pada perkusi didapatkan suara timpani. Pada pemeriksaan ekstremitas teraba hangat, edema pada kedua tangan dan tungkai, tidak ada bintik kemerahan/ ruam. Hasil pemeriksaan laboratorium RSUP Prof. Dr. R. D. Kandou tanggal 17 Juli 2018 ialah sebagai berikut: $\mathrm{Hb} 8,1 \mathrm{~g} / \mathrm{dL}$; eritrosit 2,78x $10^{6} / \mathrm{uL}$; Ht $22 \%$; leukosit 30.900/uL; trombosit 412.000/uL; MCH 29,1 pg; MCHC 36,8 g/dL; MCV 79,1 fL; SGOT $12 \mathrm{U} / \mathrm{L} ;$ SGPT $19 \mathrm{U} / \mathrm{L} ;$ GDS 92 $\mathrm{mg} / \mathrm{dL}$; ureum $145 \mathrm{mg} / \mathrm{dL}$; kreatinin 9,1 $\mathrm{mg} / \mathrm{dL} ; \mathrm{Na} 119 \mathrm{mEq} / \mathrm{L} ; \mathrm{K}$ 4,4 mEq/L; Cl 85 $\mathrm{mEq} / \mathrm{L} ;$ PT 15,2 detik; INR 1,16 detik; APPT 48,4 detik. Hasil konsultasi ke Bagian Obstetri-Ginekologi ialah pasien didiagnosis $\mathrm{P}_{0} \mathrm{~A}_{0} 35$ tahun pasca laparoskopi miomektomi dengan massa uterus dan disarankan untuk perbaikan keadaan umum sebelum tindakan operatif. Hasil konsultasi ke Bagian Jantung pasien didiagnosis cardiorenal syndrome (CRS) type 3 dan disarankan terapi drips furosemide $240 \mathrm{mg} / \mathrm{hari}$ secara IV, gliseril trinitrat $2,5 \mathrm{mg} 2 \mathrm{x} / \mathrm{hari}$.

Berdasarkan anamnesis, pemeriksaan fisik, dan pemeriksaan penunjang, pasien didiagnosis GgGA et kausa sepsis, sepsis et kausa infeksi intraabdomen dd pneumonia, cardiorenal syndrome type 3, pasca operasi mioma uteri, anemia et kausa perdarahan pasca operasi, hiperurisemia, hiponatremia dilusional. Terapi disarankan cairan adekuat dengan target balans cairan seimbang, diet ginjal non dialisis protein $0,8 \mathrm{~g} / \mathrm{kgBB} / \mathrm{hari}$, kalori $35 \mathrm{kkal} / \mathrm{kgBB} /$ hari, transfusi packed red cells (PRC) selang sehari sampai $\mathrm{Hb} \geq 10$ 
$\mathrm{g} / \mathrm{dL}$, ceftriaxone $2 \mathrm{~g}$ 1x/hari IV, alopurinol $100 \mathrm{mg}$ 1x/hari. Hasil konsultasi ke Divisi Ginjal-Hipertensi ialah pasien didiagnosis dengan GgGA (failure) et kausa sepsis, sepsis et kausa infeksi intraabdomen dd pneumonia, cardiorenal syndrome type 3, pasca operasi mioma uteri, anemia et kausa perdarahan pasca operasi, hiperurisemia, hiponatremia dilusional. Disarankan terapi suportif ginjal hemodialisis (TSG-HD), diet ginjal non dialisis protein $0,8 \mathrm{~g} / \mathrm{kgBB} / \mathrm{hari}$, kalori $35 \mathrm{kkal} / \mathrm{kgBB} /$ hari saat ini, takar urine balans cairan seimbang, serta koreksi elektrolit dan anemia.

Pada tanggal 18 Juli 2018, pasien dialih rawat ke bagian IPD dan dilakukan pemeriksaan laboratorium kontrol dengan hasil sebagai berikut: ureum $143 \mathrm{mg} / \mathrm{dL}$; kreatinin 9,4 mg/dL; Na 119 mEq/L; K 4,16 mEq/L; $\mathrm{Cl}$ 79,2 $\mathrm{mEq} / \mathrm{L}$. Pasien dikonsulkan ke Program Pengendalian Resistensi Antimikroba (PPRA) dan disarankan untuk pemberian antibiotik injeksi ampicillinsulbactam. Selanjutnya pasien diperiksakan urinalisis lengkap dengan hasil makroskopik warna kuning keruh, mikroskopik eritrosit $>50 / \mathrm{LPB}$, leukosit 8-10/LPB, epitel 56/LPK, kimia berat jenis 1010, pH 5, leukosit $(+2)$, nitrit $(-)$, protein $(+1)$, glukosa $(-)$, keton (-), urobilinogen (-), bilirubin (-), darah/eritrosit $(+5)$. Keluhan saat tersebut sesak berkurang, kaki bengkak berkurang, terdapat nyeri perut. Pemeriksaan fisik ditemukan tekanan darah 100/70 $\mathrm{mmHg}$, nadi $110 \mathrm{x} / \mathrm{menit}$ reguler, isi cukup, frekuensi pernapasan $24 \mathrm{x} /$ menit, suhu badan aksiler $38,9^{\circ} \mathrm{C}$, ronki basah kasar pada kedua basal paru, nyeri tekan epigastrium. Pasien didiagnosis dengan GgGA (failure) et kausa sepsis, sepsis et kausa infeksi intraabdomen dd pneumonia, cardiorenal syndrome type 3, pasca operasi mioma uteri, anemia et kausa perdarahan pasca operasi, hiperurisemia, hiponatremia dilusional. Diberikan infus EAS pfrimmer $250 \mathrm{~mL} 7$ tetes/ menit, injeksi ampicillin-sulbactam 1,5 g $3 \mathrm{x} /$ hari secara IV, injeksi ranitidine $50 \mathrm{mg}$ $2 \mathrm{x} /$ hari secara IV, natrium bikarbonat 500 $\mathrm{mg} 3 \mathrm{x} / \mathrm{hari}$, transfusi PRC $230 \mathrm{~mL}$ setiap selang 1 hari sampai $\mathrm{Hb} \geq 10 \mathrm{~g} / \mathrm{dL}$, takar urine balans cairan seimbang, diet ginjal non dialisis protein $0,8 \mathrm{~g} / \mathrm{kgBB} /$ hari, kalori 35 $\mathrm{kkal} / \mathrm{kgBB} / \mathrm{hari}$. Pasien dikonsulkan ke PPRA dan disarankan pemakaian antibiotik injeksi cefoperazone-sulbactam $500 \mathrm{mg}$ 2x/hari secara IV. Hasil konsultasi ke Bagian Bedah Digestif pasien didiagnosis kolik abdomen dan disarankan untuk computerized tomography (CT) scan dengan kontras bila fungsi ginjal baik. Pasien juga dikonsulkan ke Bagian Bedah Vaskular untuk pemasangan akses vaskular yaitu double lumen catheter (DLC). Dilakukan pemeriksaan laboratorium dengan hasil sebagai berikut: $\mathrm{Hb} 7,8 \mathrm{~g} / \mathrm{dL}$; eritrosit 2,65×10\%/uL; Ht 21,2\%; leukosit 25.500/uL; trombosit 399.000/uL; MCH 29,4 pg; MCHC 36,8 g/dL; MCV 80 fL; Anti HCV kualitatif non reaktif; HBsAg Elisa non reaktif; Anti HIV (Elisa) non reaktif, dan diperiksakan urinalisis lengkap dengan hasil makroskopik warna kuning jernih, mikroskopik eritrosit >50/LPB, leukosit >50/LPB, epitel 0-1/LPK, kimia berat jenis 1010, pH 5 , leukosit $(+3)$, nitrit $(-)$, protein $(+1)$, glukosa (-), keton (-), urobilinogen $(-)$, bilirubin (-), darah/eritrosit (+5).

Hari ke-3 perawatan tanggal 19 Juli 2018, pasien mengeluh sesak berkurang, kaki bengkak berkurang, nyeri perut berkurang. Pemeriksaan fisik ditemukan tekanan darah 120/80 mmHg, nadi $74 \mathrm{x} /$ menit reguler, isi cukup, frekuensi pernapasan $20 \mathrm{x} /$ menit, suhu badan aksiler $36,8^{\circ} \mathrm{C}$, konjungtiva anemis ronki basah kasar pada kedua basal paru, tidak ada nyeri tekan epigastrium, edema kedua tungkai dan urine output $1200 \mathrm{~mL} / 15$ jam. Terapi dilanjutkan. Dilakukan pemeriksaan laboratorium dengan hasil $\mathrm{Hb} 8,7 \mathrm{~g} / \mathrm{dL}$; eritrosit 2,94×106/uL; Ht 23,8\%; leukosit 30.800/uL; trombosit 432.000/uL; MCH 29,6 pg; MCHC 36,6 g/dL; MCV $81 \mathrm{fL}$; eosinofil $1 \%$; basofil $1 \%$; netrofil batang $5 \%$; netrofil segmen $80 \%$; limfosit $6 \%$; monosit $7 \%$; eosinofil 307/uL. Hasil patologi anatomi tanggal 19 Juli 2018 kesan leiomioma uteri. Pasien dilakukan TSG-HD dengan akses vaskular HD DLC pada vena jugularis interna dekstra. Pasien kemudian diberikan 
diet ginjal dialisis protein $1,2 \mathrm{~g} / \mathrm{kgBB} / \mathrm{hari}$, kalori $35 \mathrm{kkal} / \mathrm{kgBB} / \mathrm{hari}$.

Hari ke-4 perawatan tanggal 20 Juli 2018, pasien mengeluh sesak berkurang, kaki bengkak berkurang, nyeri perut hilang timbul. Pemeriksaan fisik ditemukan tekanan darah $120 / 70 \mathrm{mmHg}$, nadi $80 \mathrm{x} /$ menit reguler, isi cukup, frekuensi pernapasan 20 $\mathrm{x} /$ menit, suhu badan aksiler $36,8^{\circ} \mathrm{C}$, konjungtiva anemis ronki basah kasar pada kedua basal paru, edema kedua tungkai dan urine output $1200 \mathrm{~mL} / 21$ jam. Terapi dilanjutkan kemudian dilakukan pemeriksaan laboratorium dengan hasil $\mathrm{Hb} 7,6 \mathrm{~g} / \mathrm{dL}$; eritrosit 2,57x10\% $32.100 / \mathrm{uL}$; trombosit $421.000 / \mathrm{uL} ; \mathrm{MCH}$ 29,6 pg; MCHC 36,7 g/dL; MCV 80,5 fL; GDS $107 \mathrm{mg} / \mathrm{dL}$; ureum $111 \mathrm{mg} / \mathrm{dL}$; kreatinin 6,6 mg/dL; Na 129 mEq/L; K 3,8 $\mathrm{mEq} / \mathrm{L} ; \mathrm{Cl} 98 \mathrm{mEq} / \mathrm{L}$.

Hari ke-5 perawatan tanggal $21 \mathrm{Juli}$ 2018, pasien mengeluh nyeri perut berkurang. Pemeriksaan fisik ditemukan tekanan darah $120 / 70 \mathrm{mmHg}$, nadi $80 \mathrm{x} /$ menit reguler, isi cukup, frekuensi pernapasan $20 \mathrm{x} /$ menit, suhu badan aksiler $36,7^{\circ} \mathrm{C}$, konjungtiva anemis dan urine output 2100 $\mathrm{mL} / 24$ jam. Terapi dilanjutkan dan dilakukan TSG-HD.

Hari ke-6 perawatan tanggal 22 Juli 2018 , pasien mengeluh nyeri perut bawah. Pemeriksaan fisik ditemukan tekanan darah $120 / 80 \mathrm{mmHg}$, nadi $80 \mathrm{x} / \mathrm{menit}$ reguler, isi cukup, frekuensi pernapasan $24 \mathrm{x} /$ menit, suhu badan aksiler $36,9^{\circ} \mathrm{C}$, konjungtiva anemis, nyeri tekan di perut kanan bawah, dan urine output $2000 \mathrm{~mL} / 24$ jam. Dilakukan pemeriksaan laboratorium dengan hasil sebagai berikut: $\mathrm{Hb} 8,9 \mathrm{~g} / \mathrm{dL}$; eritrosit 3,08×10\%/uL; Ht 27,2\%; leukosit 26.200/uL; trombosit 374.000/uL; MCH 28,9 pg; MCHC 32,7 g/dL; MCV 88,2 fL; GDS 157 $\mathrm{mg} / \mathrm{dL}$; ureum $52 \mathrm{mg} / \mathrm{dL}$; kreatinin 3,2 $\mathrm{mg} / \mathrm{dL} ; \mathrm{Na} 137 \mathrm{mEq} / \mathrm{L} ; \mathrm{K} 3,8 \mathrm{mEq} / \mathrm{L} ; \mathrm{Cl}$ $102 \mathrm{mEq} / \mathrm{L}$.

Hari ke-7 perawatan tanggal 23 Juli 2018, pasien mengeluh nyeri perut bawah. Pemeriksaan fisik ditemukan tekanan darah $130 / 80 \mathrm{mmHg}$, nadi $84 \mathrm{x} / \mathrm{menit}$ reguler, isi cukup, frekuensi pernapasan $22 \mathrm{x} /$ menit, suhu badan aksiler $37,2^{\circ} \mathrm{C}$, konjungtiva anemis, nyeri tekan di perut kanan bawah, dan urine output $2500 \mathrm{~mL} / 24$ jam. Diberikan injeksi cefoperazone-sulbactam 1000 $\mathrm{mg} 2 \mathrm{x} /$ hari secara IV dan terapi lain dilanjutkan. Hasil kultur darah tidak ada pertumbuhan bakteri. Pemeriksaan urinalisis dengan hasil makroskopik warna kuning jernih, mikroskopik eritrosit 10-15 /LPB, leukosit 2-4/LPB, epitel 0-1/LPK, kimia berat jenis 1015, pH 7, leukosit $(+1)$, nitrit (-), protein (-), glukosa (-), keton (-), urobilinogen $(-)$, bilirubin $(-)$, darah/eritrosit $(+3)$.

Hari ke-8 perawatan tanggal 24 Juli 2018, pasien mengeluh nyeri perut hilang timbul. Pemeriksaan fisik ditemukan tekanan darah 130/80 mmHg, nadi $78 \mathrm{x} /$ menit reguler, isi cukup, frekuensi pernapasan $20 \mathrm{x} / \mathrm{menit}$, suhu badan aksiler $36,5^{\circ} \mathrm{C}$, konjungtiva anemis dan nyeri tekan di perut bawah. Terapi dilanjutkan. Hasil kultur urin tidak ada pertumbuhan bakteri.

Hari ke-9 perawatan tanggal 25 Juli 2018, pasien mengeluh nyeri perut hilang timbul. Pemeriksaan fisik ditemukan tekanan darah 120/70 $\mathrm{mmHg}$, nadi $88 \mathrm{x} /$ menit reguler, isi cukup, frekuensi pernapasan 22 $\mathrm{x} /$ menit, suhu badan aksiler $36,5^{\circ} \mathrm{C}$, nyeri tekan di perut bawah dan epigastrium dengan urine output $2000 \mathrm{~mL} / 24$ jam. Terapi dilanjutkan. Dilakukan pemeriksaan laboratorium dengan hasil sebagai berikut:

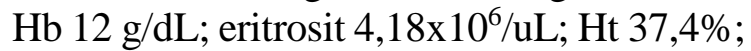
leukosit 14.200/uL; trombosit 268.000/uL; MCH 28,8 pg; MCHC 32,2 g/dL; MCV 89,4 fL; SGOT 38 U/L; SGPT 50 U/L; GDS 102 $\mathrm{mg} / \mathrm{dL}$; ureum $86 \mathrm{mg} / \mathrm{dL}$; kreatinin 2,9 $\mathrm{mg} / \mathrm{dL} ; \mathrm{Na} 140 \mathrm{mEq} / \mathrm{L} ; \mathrm{K} 3,95 \mathrm{mEq} / \mathrm{L} ; \mathrm{Cl}$ $100 \mathrm{mEq} / \mathrm{L} ;$ PT 15,7 detik; INR 1,2 detik; APPT 43,6 detik. Hasil CT scan abdomen tanpa kontras kesan suspek abses (dd. Kista kompleks ovarium yang terinfeksi), disertai fluid collection dalam kavum Douglasi.

Hari ke-10 perawatan tanggal 26 Juli 2018, pasien mengeluh nyeri perut hilang timbul. Pemeriksaan fisik ditemukan tekanan darah 120/70 mmHg, nadi $68 \mathrm{x} /$ menit reguler, isi cukup, frekuensi pernapasan $20 \mathrm{x} /$ menit, suhu badan aksiler $36,7^{\circ} \mathrm{C}$, nyeri tekan di perut bawah dan epigastrium dengan urine output $2000 \mathrm{~mL} / 24$ jam. 
Terapi dilanjutkan dan dilakukan pemeriksaan laboratorium dengan hasil sebagai berikut: $\mathrm{Hb} 12,5 \mathrm{~g} / \mathrm{dL}$; eritrosit 4,47×10\% $/ \mathrm{uL}$; Ht 38,1\%; leukosit 11.000/uL; trombosit 224.000/uL; MCH 28 pg; MCHC 32,8 g/dL; MCV 85,2 fL; GDS $87 \mathrm{mg} / \mathrm{dL}$; ureum 84 $\mathrm{mg} / \mathrm{dL}$; kreatinin $2,1 \mathrm{mg} / \mathrm{dL}$; protein total $8,4 \mathrm{~g} / \mathrm{dL}$; albumin $4,18 \mathrm{~g} / \mathrm{dL}$; globulin 4,22 g/dL; Na 140 mEq/L; K 4,3 mEq/L; Cl 103 $\mathrm{mEq} / \mathrm{L}$; PT 15 detik; INR 1,14 detik; APPT 42,2 detik.

Hari ke-11 perawatan tanggal 27 Juli 2018, pasien mengeluh nyeri perut hilang timbul. Pemeriksaan fisik ditemukan tekanan darah 110/70 $\mathrm{mmHg}$, nadi $78 \mathrm{x} /$ menit reguler, isi cukup, frekuensi pernapasan 22 $\mathrm{x} /$ menit, suhu badan aksiler $36,8^{\circ} \mathrm{C}$, nyeri tekan di perut bawah dan epigastrium. Terapi dilanjutkan. Dilakukan rekam janung dengan hasil kesan sinus rhythm, heart rate $85 \mathrm{x} /$ menit. Pada hari ini pasien dikonsulkan preoperatif untuk tindakan laparoskopi eksplorasi dengan pendampingan bedah digestif. Diagnosis pra operasi $\mathrm{P}_{0} \mathrm{~A}_{0}$ 35 tahun suspek abses intraabdomen pasca laparoskopi miomektomi, GgGA perbaikan, sepsis et kausa infeksi intra-abdomen perbaikan.

Hari ke-12 perawatan tanggal 28 Juli 2018, pasien mengeluh nyeri perut berkurang. Pemeriksaan fisik ditemukan tekanan darah $130 / 80 \mathrm{mmHg}$, nadi $82 \mathrm{x} /$ menit reguler, isi cukup, frekuensi pernapasan $22 \mathrm{x} /$ menit, suhu badan aksiler $37^{\circ} \mathrm{C}$, nyeri tekan di perut bawah dan epigastrium. Terapi dilanjutkan dan dilakukan TSG-HD perioperatif.

Hari ke-13 perawatan tanggal 29 Juli 2018, pasien mengeluh nyeri perut berkurang. Pemeriksaan fisik ditemukan tekanan darah 120/80 $\mathrm{mmHg}$, nadi $78 \mathrm{x} /$ menit reguler, isi cukup, frekuensi pernapasan $20 \mathrm{x} /$ menit, suhu badan aksiler $36,5^{\circ} \mathrm{C}$, nyeri tekan di perut bawah dan epigastrium. Terapi dilanjutkan. Dilakukan pemeriksaan laboratorium dengan hasil $\mathrm{Hb} 11,5 \mathrm{~g} / \mathrm{dL}$;

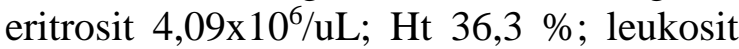
10.600/uL; trombosit 128.000/uL; $\mathrm{MCH}$ 28,2 pg; MCHC 31,8 g/dL; MCV 88,7 fL; ureum $53 \mathrm{mg} / \mathrm{dL}$; kreatinin 1,4 mg/dL; Na
137 mEq/L; K 4 mEq/L; Cl 103 mEq/L; PT 15,4 detik; INR 1,31 detik; APPT 36,2 detik.

Hari ke-14 perawatan tanggal 30 Juli 2018, pasien mengeluh nyeri perut minimal. Pemeriksaan fisik ditemukan tekanan darah $110 / 80 \mathrm{mmHg}$, nadi $78 \mathrm{x} / \mathrm{menit}$ reguler, isi cukup, frekuensi pernapasan $20 \mathrm{x} /$ menit, suhu badan aksiler $36,8^{\circ} \mathrm{C}$, nyeri tekan di perut bawah dan epigastrium dengan urine output $2000 \mathrm{~mL} / 24 \mathrm{jam}$. Terapi dilanjutkan. Hasil foto toraks kesan normal. Dilakukan operasi laparoskopi eksplorasi dengan adhesioisis dilanjutkan dengan drainase abses suprafundus uteri. Diagnosis pascabedah $\mathrm{P}_{0} \mathrm{~A}_{0} 35$ tahun abses suprafundus uteri post laparoskopi eksplorasi dengan adhesiolisis. Dilakukan pemeriksaan laboratorium dengan hasil $\mathrm{Hb} 11,2 \mathrm{~g} / \mathrm{dL}$; eritrosit 4x106/ Ht 35,9 \%; leukosit 19.800/uL; trombosit 161.000/uL; MCH 28 pg; MCHC 31,1 g/dL; MCV 89,8 fL; eosinofil 0\%; basofil 0\%; netrofil batang $1 \%$; netrofil segmen $86 \%$; limfosit 10\%; monosit 3\%; SGOT $15 \mathrm{U} / \mathrm{L}$; SGPT $29 \mathrm{U} / \mathrm{L}$; bilirubin total $0,3 \mathrm{mg} / \mathrm{dL}$; bilirubin direk $0,18 \mathrm{mg} / \mathrm{dL}$; GDS 108 $\mathrm{mg} / \mathrm{dL}$; ureum $51 \mathrm{mg} / \mathrm{dL}$; kreatinin 1,4 $\mathrm{mg} / \mathrm{dL}$; albumin 3,9 g/dL; Na $142 \mathrm{mEq} / \mathrm{L}$; K 5,1 mEq/L; Cl 106 mEq/L; Ca 8,61 mg/dL; Mg 1,57 mg/dL; P 4,8 mg/dL; PT 15,5 detik; INR 1,32 detik; APPT 35 detik.

Hari ke-15 perawatan tanggal 31 Juli 2018, pasien mengeluh nyeri luka operasi. Pemeriksaan fisik ditemukan tekanan darah $114 / 71 \mathrm{mmHg}$, nadi $88 \mathrm{x} / \mathrm{menit}$ reguler, isi cukup, frekuensi pernapasan $20 \mathrm{x} /$ menit, suhu badan aksiler $36,6^{\circ} \mathrm{C}$, konjungtiva anemis, nyeri tekan luka operasi, luka operasi terawat, dengan urine output 2500 $\mathrm{mL} / 24$ jam. Terapi dilanjutkan. Pada hasil kultur pus ditemukan kuman Enterobacter cloacae complex dengan sensitivitas terhadap antibiotik piperacillin/tazobactam, cefepime, ertapenem, meropenem, amikacin, tigecycline, trimethoprim/sulfamethoxazole, tetapi resisten terhadap antibiotik ampicillin, ampicillin-sulbactam, cefazolin, ceftazidime, ceftriaxone, aztreonam, gentamicin, cefotaxime, amoxicillin serta intermediat terhadap antibiotik ciprofloxacin dan nitrofurantoin. Pasien direncanakan pindah ruangan. 
Hari ke-16 perawatan tanggal 1 Agustus 2018, pasien mengeluh nyeri perut hilang timbul. Pemeriksaan fisik ditemukan tekanan darah 130/80 $\mathrm{mmHg}$, nadi $78 \mathrm{x} /$ menit reguler, isi cukup, frekuensi pernapasan $20 \mathrm{x} /$ menit, suhu badan aksiler $36,5^{\circ} \mathrm{C}$, konjungtiva anemis, nyeri tekan luka operasi, luka operasi terawat dengan urine output $1500 \mathrm{~mL} / 24 j a m$. Terapi dilanjutkan.

Hari ke-17 perawatan tanggal 2 Agustus 2018, pasien mengeluh nyeri perut berkurang. Pemeriksaan fisik ditemukan tekanan darah 120/80 $\mathrm{mmHg}$, nadi $76 \mathrm{x} /$ menit reguler, isi cukup, frekuensi pernapasan $20 \mathrm{x} /$ menit, suhu badan aksiler $36^{\circ} \mathrm{C}$, konjungtiva anemis, nyeri tekan luka operasi, luka operasi terawat dengan urine output $2500 \mathrm{~mL} / 24 \mathrm{jam}$. Terapi dilanjutkan dan dilakukan pemeriksaan laboratorium dengan hasil: $\mathrm{Hb}$ 10,7 $\mathrm{g} / \mathrm{dL}$; eritrosit $3,79 \times 10^{6} / \mathrm{uL}$; Ht 34\%; leukosit 8.100/uL; trombosit 238.000/uL; MCH 28,1 pg; MCHC 31,3 g/dL; MCV 89,6 fL; SGOT 17 U/L; SGPT 21 U/L; GDS 102 mg/dL; ureum $31 \mathrm{mg} / \mathrm{dL}$; kreatinin $1 \mathrm{mg} / \mathrm{dL}$; albumin 3,85 g/dL; Na 136 mEq/L; K 3,92 mEq/L; Cl 98,5 $\mathrm{mEq} / \mathrm{L}$.

Hari ke-18 perawatan tanggal 3 Agustus 2018, pasien mengeluh nyeri perut minimal. Pada pemeriksaan fisik ditemukan tekanan darah 110/80 mmHg, nadi $82 \mathrm{x} /$ menit reguler, isi cukup, frekuensi pernapasan $20 \mathrm{x} /$ menit, suhu badan aksiler $37^{\circ} \mathrm{C}$, konjungtiva anemis, nyeri tekan luka operasi minimal, luka operasi terawat. Terapi dilanjutkan.

Hari ke-19 perawatan tanggal 4 Agustus 2018, pasien tidak ada keluhan. Pemeriksaan fisik ditemukan tekanan darah $110 / 70 \mathrm{mmHg}$, nadi $82 \mathrm{x} / \mathrm{menit}$ reguler, isi cukup, frekuensi pernapasan $20 \mathrm{x} / \mathrm{menit}$, suhu badan aksiler $37^{\circ} \mathrm{C}$, konjungtiva anemis, nyeri tekan luka operasi minimal, luka operasi terawat. Terapi injeksi dihentikan diganti dengan terapi oral asam folat 400 mcg 2x/hari, vitamin B kompleks 1 tab $3 \mathrm{x} /$ hari, lansoprasole $30 \mathrm{mg} 2 \mathrm{x} / \mathrm{hari}$, dan paracetamol $500 \mathrm{mg} \mathrm{3x/hari.}$

Hari ke-20 perawatan tanggal 5 Agustus 2018, pasien tidak ada keluhan. Pemeriksaan fisik ditemukan tekanan darah
120/80 $\mathrm{mmHg}$, nadi $73 \mathrm{x} / \mathrm{menit}$ reguler, isi cukup, frekuensi pernapasan $20 \mathrm{x} /$ menit, suhu badan aksiler $36,5^{\circ} \mathrm{C}$, nyeri tekan luka operasi minimal, luka operasi terawat. Terapi dilanjutkan. Dilakukan pemeriksaan laboratorium dengan hasil: $\mathrm{Hb} 11,6 \mathrm{~g} / \mathrm{dL}$; eritrosit 4,16×10\% $\mathrm{uL}$; Ht 37,2 \%; leukosit 8.400/uL; trombosit 290.000/uL; MCH 27,9 pg; MCHC 31,2 g/dL; MCV 89,4 fL; ureum $20 \mathrm{mg} / \mathrm{dL}$; kreatinin $0,9 \mathrm{mg} / \mathrm{dL}$.

Hari ke-21 perawatan tanggal 6 Agustus 2018, pasien tidak ada keluhan. Pemeriksaan fisik ditemukan tekanan darah $120 / 80 \mathrm{mmHg}$, nadi $73 \mathrm{x} / \mathrm{menit}$ reguler, isi cukup, frekuensi pernapasan $20 \mathrm{x} /$ menit, suhu badan aksiler $36,5^{\circ} \mathrm{C}$, nyeri tekan luka operasi minimal, luka operasi terawat. Terapi dilanjutkan. Dilakukan pemeriksaan laboratorium dengan hasil: $\mathrm{Hb} 11,4 \mathrm{~g} / \mathrm{dL}$; eritrosit 4,08×106\% 10.300/uL; trombosit 296.000/uL; MCH 28 pg; MCHC 31,9 g/dL; MCV 87,9 fL; SGOT $15 \mathrm{U} / \mathrm{L}$; SGPT $19 \mathrm{U} / \mathrm{L}$; ureum $34 \mathrm{mg} / \mathrm{dL}$; kreatinin 1,1 mg/dL; GDS $89 \mathrm{mg} / \mathrm{dL}$; Na 138 mEq/L; K 3,7 mEq/L; Cl 99 mEq/L; PT 13,3 detik; INR 1,07 detik; APPT 29,2 detik.

Hari ke-22 perawatan tanggal 7 Agustus 2018, pasien tidak ada keluhan. Pemeriksaan fisik ditemukan tekanan darah $120 / 70 \mathrm{mmHg}$, nadi $82 \mathrm{x} / \mathrm{menit}$ reguler, isi cukup, frekuensi pernapasan $21 \mathrm{x} /$ menit, suhu badan aksiler $37^{\circ} \mathrm{C}$, nyeri tekan luka operasi minimal, luka operasi terawat. Double lumen catheter dilepas kemudian pasien rawat jalan dengan terapi vitamin $\mathrm{B}$ kompleks 1 tab 3x/hari, lansoprasole $30 \mathrm{mg}$ $2 \mathrm{x} /$ hari, dan paracetamol $500 \mathrm{mg} \mathrm{3x} /$ hari kalau perlu. Pasien disarankan untuk perawatan luka mandiri dan kontrol rutin di Poliklinik Ginjal-Hipertensi RSUP Prof. Dr. R. D. Kandou Manado.

\section{BAHASAN}

Gangguan ginjal akut berdasarkan kriteria Kidney Disease: Improving Global Outcomes (KDIGO) yaitu peningkatan kadar kreatinin serum $\geq 0,3 \mathrm{mg} / \mathrm{dL}(\geq 26,5 \mu \mathrm{mol} / \mathrm{L})$ dalam 48 jam, atau presentasi kenaikan kadar kreatinin serum $\geq 50 \%$ (1,5 kali kenaikan nilai dasar) dalam 7 hari, atau produksi urin $<0,5 \mathrm{~mL} / \mathrm{kg} / \mathrm{jam}$ dalam waktu 6 jam). ${ }^{1}$ 
Populasi berisiko tinggi GgGA akibat sepsis telah diidentifikasi. Pasien usia lanjut memiliki tingkat kejadian GgGA akibat sepsis yang lebih tinggi. Selain itu, wanita ditemukan lebih sering dibandingkan pria. Komorbid dasar, khususnya penyakit ginjal kronik (PGK), diabetes melitus, gagal jantung, keganasan, dan penyakit hati meningkatkan kerentanan pasien terhadap GgGA akibat sepsis. Sumber-sumber sepsis khususnya dari infeksi aliran darah, sepsis abdomen dan genitourinarius, endokarditis infektif, mempunyai kemungkinan yang lebih tinggi untuk terjadinya GgGA. Keterlambatan pemberian terapi antimikroba yang tepat terbukti menjadi prediktor independen terhadap perkembangan GgGA. Penundaan tambahan dalam pemberian antimikroba setelah timbulnya hipotensi menunjukkan hubungan langsung dengan perkembangan GgGA. Pada kasus ini pasien ialah seorang wanita berusia 35 tahun masuk rumah sakit dengan sepsis nosokomial intraabdomen dari operasi laparoskopi miomektomi, pasien sudah diberikan terapi antibiotik yang adekuat dari perawatan di rumah sakit sebelumnya, tetapi proses operatif untuk drainase abses harus menunggu perbaikan keadaan umum pasien. ${ }^{2-4}$

Penyebab GgGA secara garis besar dibagi menjadi 3 bagian, yaitu pre-renal, renal (intrinsik), post-renal. Gangguan ginjal akut pre-renal akibat dari hipoperfusi ginjal menyebabkan penurunan laju filtrasi glomerulus (LFG) tanpa merusak parenkim ginjal, sebagai respons adaptif terhadap berbagai pengaruh ekstrarenal. Telah diketahui bahwa untuk mempertahankan LFG normal tergantung pada perfusi ginjal yang adekuat. Ginjal menerima hingga 25\% dari curah jantung dan dengan demikian setiap kegagalan volume sirkulasi darah sistemik atau kegagalan terisolasi dari sirkulasi intrarenal dapat memiliki dampak mendalam pada perfusi ginjal. Etiologi GgGA renal (intrinsik) dapat menjadi tantangan untuk dievaluasi karena berbagai macam cedera dapat terjadi pada ginjal. Secara umum, terdapat empat struktur ginjal yang terlibat termasuk tubulus, glomerulus, interstisial, dan pembuluh darah intrarenal. Istilah nekrosis tubular akut digunakan untuk menunjuk GgGA yang disebabkan dari kerusakan tubulus. Tipe ini merupakan yang paling umum dari cedera ginjal intrinsik. Gangguan ginjal akut dari kerusakan glomerulus terjadi pada kasus glomerulonefritis (GN) akut yang berat. Gangguan ginjal akut akibat kerusakan pembuluh darah terjadi karena cedera pada pembuluh darah intrarenal menurunkan perfusi ginjal dan mengurangi LFG dan akhirnya terjadi nefritis interstisial akut karena reaksi alergi terhadap berbagai obat atau infeksi. Gangguan ginjal akut post-renal terjadi setelah obstruksi akut aliran urin, yang meningkatkan tekanan intratubular, dan dengan demikian menurunkan LFG. ${ }^{3-6}$

Pemahaman saat ini tentang patofisiologi terjadinya GgGA akibat sepsis belum diketahui secara lengkap. Hipoperfusi yang dimediasi oleh sepsis menyebabkan nekrosis tubular disebut sebagai patofisiologi utama untuk GgGA akibat sepsis, namun demikian, semakin banyak bukti yang menantang paradigma ini. Banyak penyebab yang sekarang diakui berperan dalam terjadinya GgGA akibat sepsis, termasuk cedera iskemia-reperfusi pada glomerulus, inflamesi pada bagian spesifik nefron, hipoksia atau stres oksidatif, sitokin dan kemokin menyebabkan cedera langsung pada tubulus, serta apoptosis tubular dan mesenkimal. Tingkat keparahan cedera dan hasil akhir buruk terhadap GgGA akibat sepsis disebabkan karena keterlambatan pengenalan dini dari cedera. Kasus ini pasien mengalami GgGA intrinsik yang disebabkan oleh sepsis intraabdomen. ${ }^{6-8}$

Beberapa definisi konsensus telah dikembangkan untuk memberikan kriteria yang seragam untuk diagnosis GgGA. Pada tahun 2004, kelompok Acute Dialysis Quality Initiative (ADQI) mengusulkan pedoman konsensus dan pengobatan berbasis bukti serta pencegahan GgGA, yang kemudian disebut kriteria RIFLE (Risk, Injury, Failure, Loss, dan End-stage kidney disease). Modifikasi kriteria ini kemudian diusulkan oleh Acute Kidney Injury Network 
(AKIN, yang termasuk kelompok ADQI). Kelompok studi GgGA KDIGO mengusulkan definisi yang dimodifikasi, menggabungkan perbedaan antara definisi RIFLE dan AKIN. Pada kasus ini pasien diklasifikasikan ke dalam GgGA tahap 3 berdasarkan kriteria KDIGO dan termasuk dalam tahap failure bila menggunakan kriteria RIFLE dimana terdapat peningkatan kreatinin dari $0,7 \mathrm{mg} / \mathrm{dL}$ menjadi $9,1 \mathrm{mg} / \mathrm{dL}$ sedangkan dari urine output masih dalam keadaan cukup dimana urine output dalam 24 jam $\pm 1.500-2.000 \mathrm{~mL}^{8-10}$

Pada pasien dengan sepsis abdominal, deteksi dan perawatan dini sangatlah penting untuk meminimalkan komplikasi. Pasien mengeluh nyeri perut, yang awalnya terasa sejak setelah operasi mioma uteri, rasa nyeri tumpul dan tidak terlokalisir dengan baik dan sering berkembang menjadi nyeri yang stabil, berat, dan lebih terlokalisir. ${ }^{2,8,9}$

Kriteria untuk diagnosis sepsis pertama kali dibentuk oleh American College of Chest Physician (ACCP) dan Society of Critical Care Medicine (SCCM) pada tahun 1991 dan direvisi kembali pada tahun 2001, 2016, dan 2017 sehingga membagi sepsis berdasarkan tatalaksana yang dibuat sebagai protokol (Surviving Sepsis Guidelines) dan dinilai dengan skor Sequential Organ Failure Assesment (SOFA). Definisi sepsis menurut revisi kriteria protokol Surviving Sepsis Guidelines 2017 adalah keadaan disfungsi organ yang mengancam jiwa yang disebabkan karena disregulasi respon tubuh terhadap infeksi. Pengelompokan diagnosis sepsis saat ini hanya menjadi 2 yaitu pasien dengan sepsis dan syok sepsis. Penggunaan Systemic Inflammatory Response Syndrome (SIRS) dan sepsis berat sudah tidak dipakai lagi. Komponen dasar dari revisi protokol terbaru sepsis dan syok septik ialah resusitasi awal, kontrol sumber infeksi, diagnosis (kultur dan pemeriksaan radiologik), tatalaksana suportif (ventilasi mekanik, dialisis, transfusi) dan pencegahan infeksi. Seorang pasien dikatakan sepsis bila terdapat peningkatan skor SOFA $\geq 2$. Syok sepsis didefinisikan sebagai keadaan sepsis dimana terjadi abnormalitas sirkulasi dan metabolik yang dapat menyebabkan disfungsi organ dan kematian, dengan ditandai dengan kriteria klinis sepsis dengan hipotensi persisten yang membutuhkan pemberian vasopresor untuk menjaga mean arterial pressure (MAP) $\geq 65 \mathrm{mmHg}$ dengan kadar laktat $\geq 2 \mathrm{mmol} / \mathrm{L}$ walaupun telah diberikan cairan adekuat sebelumnya. Pada pasien ini didiagnosis dengan sepsis karena infeksi abdominal dan riwayat pemberian antibiotik sebelumnya, jumlah skor SOFA 4 yaitu adanya GgGA dengan jumlah kreatinin $>5$ $\mathrm{mg} / \mathrm{dL}$, dan ditemukan positif biakan organisme yang diambil langsung dari abses intraabdominal melalui intervensi bedah laparotomi. ${ }^{2,8,9}$

Pendekatan diagnostik untuk membuktikan sumber infeksi abdomen pada pasien sepsis tergantung pada stabilitas hemodinamik pasien. Sumber infeksi intraabdomen pada pasien yang tidak stabil sebaiknya dideteksi dengan USG. Ultrasonografi abdomen memiliki keuntungan portabel sehingga dapat membantu dalam evaluasi kuadran kanan atas (misalnya abses perihepatik, kolesistitis, pankreatitis), kuadran kanan bawah, dan patologi pelvis (misalnya appendisitis, abses tuboovarium, abses kavum Douglasi), tetapi pemeriksaan ini kadang terbatas karena ketidaknyamanan pasien, distensi abdomen, dan gangguan gas pada usus. Ketika pasien stabil, CT merupakan modalitas pencitraan pilihan untuk sebagian besar proses intraabdomen. Computed tomography abdomen dan pelvis, bila memungkinkan untuk dilakukan, menjadi studi diagnostik pilihan untuk infeksi intraabdomen. Computed tomography dapat mendeteksi sejumlah kecil cairan, area peradangan, dan patologi saluran cerna lainnya dengan sensitivitas yang sangat tinggi. Pada kasus ini, dari anamnesis, pasien mempunyai keluhan sesak napas yang dirasakan saat istirahat maupun berjalan, nyeri perut menjalar sampai belakang dirasakan hilang timbul setelah pasien dioperasi atas indikasi mioma uteri, mual dan muntah dialami pada saat pasien makan. Pada pemeriksaan fisik didapatkan tekanan darah 100/70 mmHg, nadi $110 \mathrm{x} /$ menit reguler, isi cukup, frekuensi pernapasan 
$24 x /$ menit, suhu badan aksiler $38,9^{\circ} \mathrm{C}$, konjungtiva anemis, abdomen tampak datar, luka operasi terawat, bising usus normal, lemas, shifting dullness positif, defans muskular tidak ada, hati dan lien tidak teraba, nyeri tekan pada daerah epigastrium dan perut bagian bawah dengan hasil pemeriksaan laboratorium tanggal $17 \mathrm{Juli}$ 2018 leukosit 30.900/uL. Hasil CT scan abdomen tanpa kontras kesan suspek abses (dd. Kista kompleks ovarium yang terinfeksi), disertai fluid collection dalam kavum Douglasi dan hasil USG abdomen kesan massa hipoekoik di fundus uteri $\mathrm{dd} /$ hematoma, pseudokista, dan didapatkan cairan bebas di kavum Douglasi. ${ }^{9,11,12}$

Infeksi intraabdomen pascaoperasi didiagnosis dengan pemeriksaan radiologis atau pengamatan intraoperatif dalam 30 hari setelah operasi. Sampel diperoleh dari intervensi bedah (laparotomi atau drainase perkutan dari abses), drain intraabdomen dimasukkan intraoperatif, atau saluran drainase bilier dikultur. Tujuh organisme utama yang diisolasi dari infeksi intraabdomen pasca operasi (Eschericia coli, Klebsiella pneumoniae, Enterobacter cloacae, Pseudomonas aeruginosa, spesies kelompok Bacteroides fragilis, Staphylococcus aureus, dan Enterococcus faecalis) dikumpulkan di 26 pusat medis sekitar Jepang antara Januari 2014 dan Februari 2015 dan dirujuk ke laboratorium pusat (Pusat Penelitian Obatobatan Anti-infeksi di Institut Kitasato, Tokyo, Jepang). Pada kasus ini dilakukan kultur pus dari abses suprafundus uteri pasca laparoskopi eksplorasi dan adhesiolisis dengan hasil ditemukan kuman Enterobacter cloacae complex (Gram negatif). Pada pasien ini awalnya diberikan antibiotik spektrum luas untuk Gram negatif dan positif ampicillin-sulbactam, setelah hasil kultur kuman selesai maka disesuaikan sesuai dengan sensitivitas kuman Enterobacter cloacae complex terhadap antibiotik. $2,8,13$

Pengontrolan mikroorganisme dengan cepat masih menjadi pilihan utama pengobatan sepsis. Tingkat kelangsungan hidup pasien dengan sepsis menurun $7,6 \%$ setiap jam dari penundaan pemberian antibiotik yang tepat. Pada GgGA terkait sepsis, perubahan tonus pembuluh darah merupakan penyebab utama hipotensi dan cedera ginjal. Norepinefrin mempertahankan tekanan arteri rerata dan meningkatkan sirkulasi meduler ginjal tanpa perubahan aliran darah ginjal sehingga memperbaiki fungsi ginjal baik pada hewan coba dan manusia. Norepinefrin juga mengembalikan kecepatan normal kapiler dan tekanan filtrasi sehingga norepinefrin menjadi obat lini pertama syok septik. Pada pasien ini tidak diberikan norepinefrin karena belum masuk ke fase syok sepsis. ${ }^{2,3,14,15}$

Pengobatan GgGA akibat sepsis mirip dengan penatalaksanaan sepsis secara umum yaitu pemberian antibiotik yang tepat dan terapi suportif yang baik. Pemberian cairan merupakan hal yang sangat penting dalam resusitasi terutama pada sepsis. Terapi cairan, lebih lanjut, selain mampu mengatasi syok septik juga dapat menyebabkan disfungsi ginjal yang lebih banyak melalui beberapa mekanisme misalnya peningkatan tekanan vena setelah terapi cairan secara langsung meningkatkan tekananan di interstisial ginjal dan area peritubular pada hewan coba. Pemberian bolus cairan dalam jumlah besar $(20-30 \mathrm{~mL} / \mathrm{kg})$ dikaitkan dengan kelebihan volume sehingga pendekatan dengan volume bolus cairan yang lebih sedikit (200-500 mL) saat ini direkomendasikan. Acute Dialysis Quality Initiative menyarankan pendekatan terapi cairan pada sepsis dengan membagi menjadi empat tahap yaitu penyelamatan, optimalisasi, stabilisasi, dan de-eskalasi. Resusitasi volume tinggi diperlukan selama tahap penyelamatan diikuti optimalisasi dan protokol stabilisasi tergantung masing-masing pasien. Setelah itu, de-eskalasi terdiri dari berkurangnya total cairan air pada pasien dimana diuretik atau terapi pengganti ginjal. Pada pasien ini dilakukan hingga tahap deeskalasi dengan penggunaan diuretik dosis maksimal dan TSG-HD. ${ }^{3,4,5,13}$

Cardio Renal Sydrome (CRS) type 3 atau disebut sindrom kardiorenal tipe 3 (sindrom renokardiak akut) ditandai oleh 
perburukan fungsi ginjal akut (AKI, iskemia, atau sepsis) yang menyebabkan disfungsi jantung akut (gagal jantung, aritmia, iskemia). Sindrom kardiorenal tipe 3 lebih jarang ditemukan dibanding tipe I, mungkin disebabkan karena hal tersebut belum diteliti secara lebih sistematik. AKI dapat memengaruhi jantung melalui beberapa cara. Kelebihan cairan berperan dalam terjadinya edema paru. Hiperkalemia dapat menyebabkan aritmia dan henti jantung. Uremia dapat mempengaruhi kontraktilitas miokard melalui akumulasi faktor-faktor depresan miokard dan perikarditis. Kondisi asidosis mempunyai efek inotropik negatif dan bersama imbalans elektrolit meningkatkan risiko aritmia. Iskemia ginjal sendiri dapat mempresipitasi aktivasi inflamasi dan apoptosis pada otot jantung. Kondisi khusus yang berkaitan dengan sindrom renokardiak akut ialah stenosis arteri renalis bilateral. Penderita dengan kondisi ini rentan mengalami gagal jantung akut atau dekompensasi akut disebabkan oleh disfungsi diastolik yang berhubungan dengan kenaikan tekanan darah akibat aktivasi berlebih aksis Renin-Agiotensin-Aldosteron-System (RAAS) disfungsi ginjal dengan retensi garam dan air, dan iskemia miokard akut disebabkan oleh peningkatan kebutuhan oksigen miokard akibat vasokonstriksi perifer yang terus menerus. Blokade angiotensin yang dibutuhkan dalam pengelolaan hipertensi dan gagal jantung pada penderitapenderita tersebut akan menyebabkan penurunan GFR dan perburukan fungsi ginjal. Pada pasien ini, infeksi intraabdominal yang tidak diobati dengan tuntas menyebabkan pasien jatuh dalam kondisi sepsis, sehingga terjadinya GgGA, retensi cairan, overload cairan, uremia, dan sindrom renokardiak akut (sindrom kardiorenal tipe 3) dimana terjadi Acute Heart Failure pada saat pasien dirawat di RS Bethesda Tomohon. ${ }^{3,8,12}$

Asidosis sering terjadi pada pasien dengan sepsis yang mungkin disebabkan oleh asidosis laktat, asidosis respiratorik, dan/atau asidosis metabolik hiperkloremik dari volum tinggi normal saline. Pengobatan bikarbonat intravena tidak dianjurkan kecuali $\mathrm{pH}$ darah lebih rendah dari 7,15.
Peningkatan perfusi jaringan, penyesuaian mesin pernapasan yang tepat, dan pemberian keseimbangan normal saline volume tinggi dengan terapi cairan lainnya (missalnya cairan keseimbangan lainnya) dapat membantu. ${ }^{2,12,14}$

Empat aspek umum terapi suportif ginjal (indikasi, waktu, modalitas, dan dosis yang diberikan) serta indikasi klinis terapi suportif ginjal (asidosis, gangguan elektrolit, intoksikasi, kelebihan cairan, dan uremia) harus diterapkan pada GgGA akibat sepsis begitu juga dengan penyebab GgGA lainnya. Data waktu inisiasi terapi suportif ginjal masih heterogen, tidak konklusif, dan tergantung dari pusat penelitian). Efek samping penundaan inisiasi terapi suportif ginjal telah dilaporkan dengan tingkat kematian yang lebih tinggi dan hasil akhir ginjal yang lebih buruk pada GgGA akibat sepsis. Pilihan modalitas HD untuk pasien dengan GgGA akibat sepsis juga penting. Walaupun pilihan modalitas HD terbaik pada GgGA akibat sepsis masih inkonklusif, hanya beberapa penelitian yang menunjukkan manfaat continuous renal replacement therapy (CRRT) dibandingkan intermittent hemodialysis (IHD) dalam kelangsungan hidup dan durasi sebelum pemulihan ginjal. Manfaat pemulihan ginjal lebih unggul pada CRRT dibandingkan dengan IHD, dikarenakan kontrol cairan yang lebih baik dengan episode hipotensi lebih rendah tetapi kelemahan CRRT biayanya mahal. Dosis prescription CRRT pada 30-35 $\mathrm{mL} / \mathrm{kg} / \mathrm{jam}$ atau tambahan $25 \%$ dari dosis CRRT yang biasa direkomendasikan oleh beberapa pusat penelitian untuk memastikan dosis yang diberikan cukup. Intermittent hemodialysis atau sustained low-efficiency dialysis (SLED) sebagai pilihan pertama modalitas terapi pengganti ginjal diikuti dengan dosis standar continuous venovenous hemofiltration (CVVH) (20-25 $\mathrm{mL} / \mathrm{kg} / \mathrm{jam}$ ) pada GgGA akibat sepsis tergantung kondisi pasien. Pada kasus ini pasien diberikan balans cairan seimbang untuk mengurangi hipoperfusi pada ginjal, antibiotik adekuat diberikan sejak awal pasien dirawat dengan pemilihan antibiotik spektrum luas khususnya untuk Gram 
negatif dan positif dan selanjutnya mengikuti hasil sensitivitas kultur pus dari abses, serta diberikan terapi suportif ginjal dengan IHD untuk intervensi dari GgGA akhir agar dapat menyelamatkan fungsi nefron yang mengalami iskemik akut, sehingga tidak terjadi iskemik kronik yang dapat menyebabkan PGK. Tindakan operatif laparoscopy exploration dilakukan setelah ada hasil CT Scan untuk membersihkan sumber infeksi dan drainase abses. ${ }^{2,3,11,15}$

\section{SIMPULAN}

Telah dilaporkan seorang pasien wanita usia 35 tahun dengan gangguan ginjal akut akibat sepsis yang disebabkan abses suprafundus uteri oleh infeksi nosokomial pasca laparoskopi mioma uteri. Diagnosis ditegakkan berdasarkan anamnesis, pemeriksaan fisik, serta pemeriksaan laboratorium dan radiologi. Pasien telah diberikan pengobatan antibiotik adekuat dengan kontrol sumber infeksi serta terapi suportif ginjal menggunakan intermittent hemodialysis, operasi eksplorasi, dan drainase abses. Prognosis pasien ini ialah baik bila kondisi sepsis teratasi dan terapi suportif ginjal hemodialisis memberikan perbaikan fungsi ginjal.

\section{Konflik Kepentingan}

Penulis menyatakan tidak terdapat konflik kepentingan dalam studi ini.

\section{DAFTAR PUSTAKA}

1. Alobaidi R, Basu R, Goldstein S, Bagshaw S. Sepsis-associated acute kidney injury. Semin Nephrol. 2015;35(1):2-11.

2. Dellinger RP. The Surviving Sepsis Campaign 2014: An update on the management and performance improvement for adults in severe sepsis. Consultant. 2014;54(10).

3. KDIGO AKI Workgroup. KDIGO clinical practice guideline for AKI. Kidney Int Suppl. 2012;2:1-138.

4. Kellum JA, Sileanu FE, Murugan R, Lucko N, Shaw AD, Clermont G. Classifying AKI by urine output versus serum creatinine level. J Am Soc Nephrol. 2015;26:223138.

5. Perner A, Prowle J, Joannidis M, Young P, Hjortrup PB, Pettil€a V. Fluid management in AKI. Intensive Care Med. 2017; 43:807-15.

6. PRISM Investigators; Rowan KM, Angus DC, Bailey M, Barnato AE, Bellomo R, et al. Early, goal-directed therapy for septic shock - a patient-level meta-analysis. N Engl J Med. 2017;376:2223-34.

7. Makris K, Spanou L. Acute kidney injury: definition, pathophysiology and clinical phenotypes. Clin Biochem Rev. 2016; 37(2):85-98.

8. Singer M, Deutschman CS, Seymour CW, Hari MS, Annane D, Bauer M, et al. The third international concensus definitions for sepsis and septic shock (sepsis-3). JAMA. 2016;315(8):801-10.

9. Moore P, Hsu R, Liu K. Management of acute kidney injury: core curriculum 2018. AJKD. 2018;72(1):136-48.

10. Takesue Y, Kusachi S, Mikamo H, Sato J, Watanabe A, Kiyota $\mathrm{H}$, et al. Antimicrobial susceptibility of common pathogens isolated from postoperative intraabdominal infection in Japan. J Infect Chemoter. 2018;24:330-40.

11. Surachno R, Bandiara R. Gangguan ginjal akut (acute kidney injury). In: Setiati S, Alwi I, Sudoyo A, Simadibrata M, Setiyo-hadi B, Syam A, editors. Buku Ajar Ilmu Penyakit Dalam Jilid II (6th ed). Jakarta: Interna Publishing, 2014; p. 2147-58.

12. Ostermann M, Joannidis M. Acute kidney injury 2016: diagnosis and diagnostic workup. Crit Care. 2016;20(299):1-13.

13. Honore P, Jacobs R, Hendrickx Inne, Bag shaw S, Joannes-Boyau O, Boer W, et al. Prevention and treatment of sepsisinduced acute kidney injury: an update. Ann Intensive Care. 2015;5(51):1-10.

14. Gomez H, Kellum J. Sepsis-induced acute kidney injury. Curr Opin Crit Care. 2016; 22(6):546-53.

15. Doyle J, Forni L. Update on sepsis-associated acute kidney injury: emerging targeted therapies. Biologics. 2016;10:149-56. 